\title{
Temporal Variation in the Physicochemical Characteristics of Water Quality
}

\author{
Foez Ahmed ${ }^{1}$, A. K. M. Rashidul Alam² \\ ${ }^{1}$ Jahangianagar University, Department of Environmental Sciences, Savar, Dhaka 1342, Bangladesh \\ ahmedfoez2014@gmail.com \\ ${ }^{2}$ Jahangianagar University, Department of Environmental Sciences, Savar, Dhaka 1342, Bangladesh \\ rashidul@juniv.edu
}

\begin{abstract}
The study was performed to evaluate the water quality of Buriganga River in the context of physical and chemical properties for winter (February), summer (May) and rainy (August) season between the periods of 2010-2020 based on available published information. Insitu water quality parameters such as Temperature, Total Dissolved Solids (TDS), Electrical Conductivity (EC), pH and Dissolved Oxygen (DO) were determined at some selected locations (Mirpur Bridge, Hazaribag, Kamrangir Char, Chandnighat, Sadarghat, Dholaikhal, BD-China Friendship Bridge and Pagla) during winter (February) season, 2020. Weighted Arithmetic Water Quality Index (WAWQI) was used to calculate the water quality status of the Buriganga River. Study findings suggested that, DO concentration of water of Buriganga River was very low particularly in winter season. Biological Oxygen Demand (BOD), Chemical Oxygen Demand (COD) and turbidity concentration crossed the maximum permissible limit during winter (February) and rainy (August) seasons according to recommended standard of inland surface water of the Department of Environment (DoE), Bangladesh. The sequence of the WQI from 2010 to 2020 was 2011>2016>2017>2019>2010>2015>2017>2018>2012>2013>2020 in the winter (February) season whereas in the summer (May) and rainy (August), season the order were 2012>2011>2010>2013>2018>2016>2014>2019>2015>2017 and 2011>2012> 2010>2016>2014>2015> 2013>2017>2019>2018, respectively. The obtained results also indicate that, water of the Buriganga River is extremely polluted in winter (February) and rainy (August) seasons and it was unsuitable for drinking and fisheries purposes. The implication of these findings can be used to monitor health of riverine ecosystems which provide ecosystem services for society.
\end{abstract}

Keywords: Buriganga River, Dissolved Oxygen, Biological Oxygen Demand, Chemical Oxygen Demand, and Water Quality Index

\section{Introduction}

Bangladesh is a riverine countries in the world. For different purposes like as fishery, agriculture, sanitation, navigation, drainage, forestry and control of salinity Bangladesh depends on its river system. However, a number of rivers in this country have become biologically and hydrologically dead due anthropogenic activities, as well as variation in river water flow during different seasons [1].

Dhaka city is surrounded by four major rivers such as Buriganga, Sitalakhaya, Turag and Balu. These rivers are used for various purposes and have a great influence on the economic, environmental, agricultural and industrial growth of the city as well as the country. In September 2009, the four rivers: Buriganga, Sitalakhaya, Turag and Balu have been declared by the Department of Environment as Ecological Critical Areas (ECAs) [2]. Among the four rivers, Buriganga is one of the most polluted rivers in Bangladesh. Total length, width and depth of this river are $27 \mathrm{~km}, 400 \mathrm{~m}$ and 10m, respectively. Most of the industries and factories of Dhaka are established on the banks of the Buriganga or nearby to the river system ${ }^{[1]}$. Buriganga River is being polluted extremly due to the dumping of huge volume toxic wastes of city's thousands of industrial units and sewerage lines [3]. The river receives a large quantity of wastes (both solid waste and wastewater) by the surface runoff, untreated industrial effluents and treated sewage effluents directly or indirectly from the city of Dhaka. These wastes and solid toxic contaminate the river water which are directly affecting on its aquatic life and indirectly effect on human health [4]. This scenario increased unexpectedly day by day.

So, it is essential to evaluate the water quality of Buriganga River. Keeping these points in thinking, the present study was undertaken based on available published information to analyze some physical and chemical parameters including: Total Dissolved Solids (TDS), Electrical Conductivity (EC), $\mathrm{pH}$, Dissolved Oxygen (DO), Biological Oxygen Demand (BOD), Chemical Oxygen Demand (COD), Turbidity, Chloride, Total Suspended Solids (TSS) and Alkalinity of the River Buriganga for winter (February), summer (May) and rainy (August) season between the periods of 20102019. In addition, in-situ water quality parameters such as; Temperature, TDS, EC, $\mathrm{pH}$ and DO were determined at some selected locations during winter (February) season, 2020.Weight Arithmatic Water quality index (WAWQI) was used to evaluate the overall quality of the Buriganga River water.

\section{Literature Survey}

Much research work was conducted on Buriganga River in Bangladesh, which is effect, by industrial effluent, untreated urban sewerage, unplanned industrialization, urbanization. It has been done on the water quality of Buriganga River. Some of this work is discussed here.

Islam et al., (2019) [5] was conducted a study to evaluate the water quality of the Buriganga River. For those purpose water samples were collected at ten (10) locations in January 2016. Water sample later analyzed in laboratory. They found that most of the parameters are within the permissible limits set by Bangladesh water quality standard 
except $\mathrm{K}^{+}, \mathrm{Mn}^{2+}$, and $\mathrm{Pb}^{2+}$. They recommended that the water of Buriganga is not safe for drinking.

Fatema et al., (2018) [6] was assessed the quality of water of the river Buriganga. They collected water samples from three selected stations in wet (June-August) and dry (November-January) season during the years 2017 and 2018. They assess (temperature, DO, pH, conductivity, dissolved phosphate, manganese, lead and cadmium) concentration on the river water and shows that temperature, DO and Fe were higher in wet season than in the dry season. $\mathrm{pH}$, conductivity and phosphate were higher in dry season than in the wet season. They suggest that the water quality of the river Buriganga is being contaminated from its adjacent point and non-point sources including municipal wastewater and effluents from different industries.

Akbor et al., (2017) [7] was carried out a study to investigate the water quality at different points in the Buriganga River. They collected water samples in eight selected ghats (points) in the river of Buriganga during January to March 2016. They shows that BOD, chemical COD, EC, TDS, Salinity, Alkalinity, Turbidity and low in DO is high in the selected eight points in the Buriganga River water. The study shows that huge environmental health risks and possible ecological disruption of this river. They found that the water of Buriganga River is now in a very critical condition.

Mottalib et al., (2017) [8] was conducted a study on physicochemical parameters and heavy metal contents of water from the selected area of Buriganga and Balu River. They assess four physico-chemical parameters such as $\mathrm{pH}$, electric conductivity (EC), biochemical oxygen demand (BOD), chemical oxygen demand (COD) and six heavy metals like $\mathrm{Fe}, \mathrm{Zn}, \mathrm{Cd}, \mathrm{Cr}, \mathrm{Hg}$ and $\mathrm{Pb}$ concentration on the river water during April-May, 2016. They found that COD, BOD and heavy metal content ration of both the river water were higher than Bangladesh standard where as $\mathrm{pH}$ and EC values were within the permissible limit. The study revealed that Buriganga River is more polluted than Balu River.

Ahammed et al., (2016) [9] was performed a study to determine the water quality of the Buriganga River. For those purpose water samples were collected in three different season of Spring (January), Summer (May) and Autumn (September) at 10 different sites of Buriganga River. They found that the average DO, BOD, COD is 1.11 $\mathrm{mg} / \mathrm{l}, 82.30 \mathrm{mg} / \mathrm{l}$ and $148.45 \mathrm{mg} / \mathrm{l}$ respectively and the concentration of nitrate and phosphate was $5.92 \mathrm{mg} / \mathrm{l}$ and $5.83 \mathrm{mg} / \mathrm{l}$ respectively and the quality of water in Buriganga River is very poor.

Uddin et al., (2016) [3] was carried out a study to investigate the seasonal variation of physical and chemical properties of water in the Buriganga River. They monitor nine water quality parameters at nine stations during the winter and the rainy season within 2012-2013. From the study they found that Temperature, $\mathrm{pH}$, TDS, TSS and $\mathrm{Cl}$ ion are within the safe limit throughout the year. They also found that DO, BOD, COD concentration of Buriganga river water is relatively by low during winter (January) season due to dilution effect and concentration was high in rainy (August) season due to diverse industrial and urban activities in low water level condition.

Rahman and Bakri (2010) [10] was conducted a research to investigate the impact of industrial effluents, municipal sewage, household wastes, clinical wastes and oils on the Buriganga River water. They assess nine water quality parameters at five stations during the winter and the rainy season within 2008-2009. They found that the river water is still acceptable in both dry and wet season in terms of parameters such as temperature, $\mathrm{pH}, \mathrm{PO}_{4}-\mathrm{P}$ and $\mathrm{Pb}$. The study shows that the Buriganga River water quality is not acceptable from aquatic ecosystem perspectives for the parameters such as $\mathrm{DO}, \mathrm{BOD}_{5}, \mathrm{COD}, \mathrm{NH}_{3}-\mathrm{N}$ and $\mathrm{Cr}$ during both dry and wet season and for EC during the dry season.

Moniruzzaman et al., (2009) [1] was conducted a research to determine the pollution level of water of Buriganga River. They assess water quality parameters at 27 stations during June 2004 to April 2005. They found that Temperature, $\mathrm{pH}, \mathrm{EC}$, TDS are within the safe limit throughout the year. But DO concentration in dry season is very low due to various microbial activities and it creates an unfavorable environment for aquatic lives. They suggest that water quality of Buriganga was not safe for drinking purposes, irrigation, fisheries, recreational activities and various industrial uses for most of the periods of year.

Ali et al., (2008) [4] was carried out a study to observe the ecological health hazards of the Buriganga River and their risk to human health. They collect water sample at different spots on the river from September to December 2006. The samples are analyzed to determine water quality and associated environmental health risks. They found that the water is high in biological oxygen demand (BOD), chemical oxygen demand (COD), phosphate $\left(\mathrm{PO}_{4}^{-3}\right)$, ammonia, organic matters and nutrients, etc. The study shows that huge environmental health risks and possible ecological disruption of this river.

Every year Department of Environment (DoE) was published Surface Water Quality Report. Under this study, Surface Water Quality Report was reviewed in detail [11][18].

\section{Methodology}

The study was conducted to analyze physical and chemical properties of water in the Buriganga River through trend (temporal) analysis and to compare the values with the standard level of water quality parameters to know the suitability of water for fisheries, drinking and industrial purposes.

\section{Sampling Sites}

The water sample was collected from eight (08) different points of Buriganga River. These sites were chosen because these sites are heavily polluted by different kinds of waste discharged from industry, commercial sectors and households. The GPS coordinates of each sampling site was determined with the aid of a handheld GPS (GPS60, Garmin, USA). The location of the sampling site is given in 
Table 1and Figure 1.

Table 1: Sampling locations of Buriganga River

\begin{tabular}{|c|c|c|}
\hline Study Site & Latitude & Longitude \\
\hline Mirpur Bridge (M.B) & $23^{\circ} 47^{\prime} 3.68^{\prime \prime}$ & $90^{\circ} 20^{\prime} 7.76^{\prime \prime}$ \\
\hline Hazaribagh (H.B) & $23^{\circ} 44^{\prime} 25.69^{\prime \prime}$ & $90^{\circ} 21^{\prime} 7.19^{\prime \prime}$ \\
\hline Kamrangirchar (K.C) & $23^{\circ} 42^{\prime} 51.82^{\prime \prime}$ & $90^{\circ} 21^{\prime} 37.9^{\prime \prime}$ \\
\hline Chandnighat (C.G) & $23^{\circ} 42^{\prime} 40.82^{\prime \prime}$ & $90^{\circ} 23^{\prime} 26.3^{\prime \prime}$ \\
\hline Sadarghat (S.G) & $23^{\circ} 41^{\prime} 58.12^{\prime \prime}$ & $90^{\circ} 24^{\prime} 59.8^{\prime \prime}$ \\
\hline Dholaikhal (D.K) & $23^{\circ} 42^{\prime} 35.67^{\prime \prime}$ & $90^{\circ} 25^{\prime} 8.91^{\prime \prime}$ \\
\hline $\begin{array}{c}\text { Bangladesh China Friendship } \\
\text { Bridge (B.C.F.B) }\end{array}$ & $23^{\circ} 39^{\prime} 39.89^{\prime \prime}$ & $90^{\circ} 27^{\prime} 18.8^{\prime \prime}$ \\
\hline & $23^{\circ} 41^{\prime} 14.33^{\prime \prime}$ & $90^{\circ} 25^{\prime} 35.2^{\prime \prime}$ \\
\hline
\end{tabular}

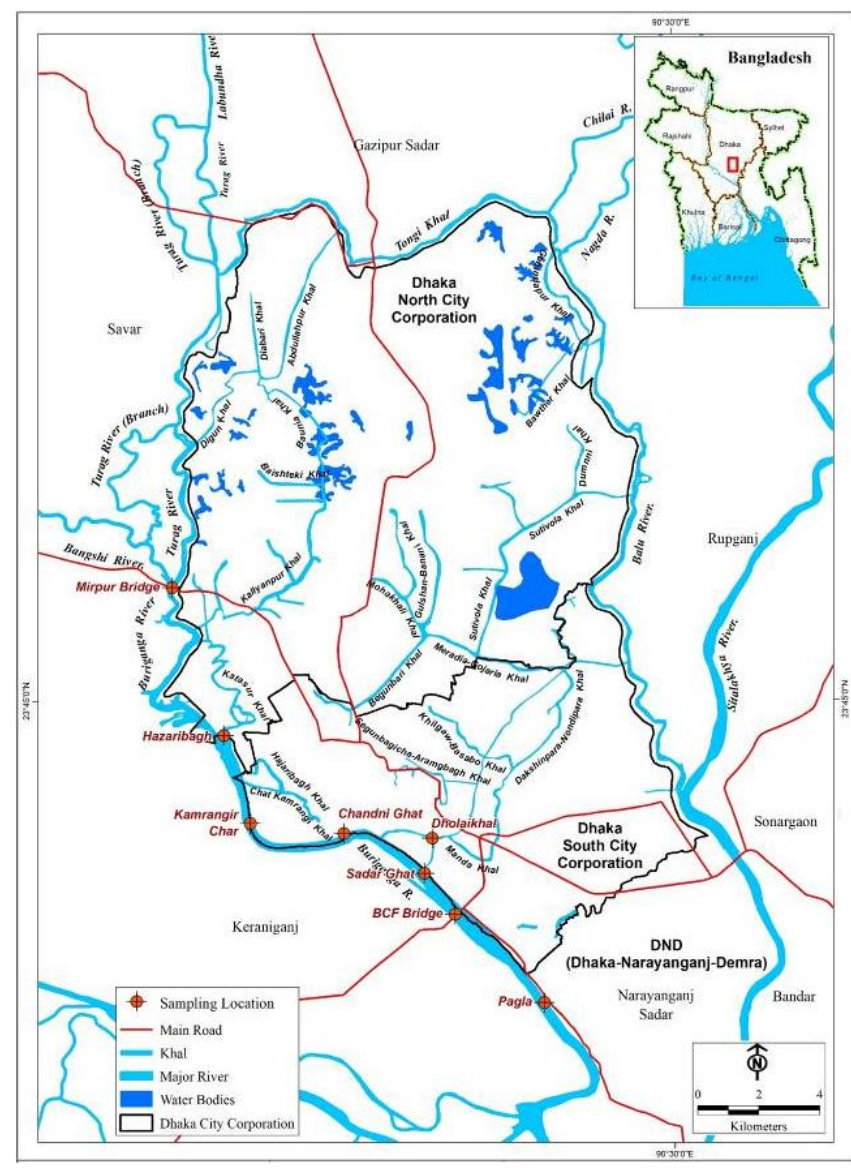

Figure 1: Water sample collection sites in Buriganga River, Dhaka, Bangladesh

\section{Assessment of Water Quality Rating based on Water Quality Index}

A relationship was proposed between water quality index (WQI) and status of water quality of a water body as mentioned in Table 2 .

Table 2: Water quality rating as per Weight Arithmetic Water Quality Index method [20]

\begin{tabular}{|c|c|c|}
\hline WQI Level & Water Quality Status & Grading \\
\hline $0-25$ & Excellent water quality & $\mathrm{A}$ \\
\hline $26-50$ & Good water quality & $\mathrm{B}$ \\
\hline $51-75$ & Poor water quality & $\mathrm{C}$ \\
\hline $76-100$ & Very poor water quality & $\mathrm{D}$ \\
\hline$>100$ & Unsuitable for drinking & $\mathrm{E}$ \\
\hline
\end{tabular}

\section{Results}

The physical and chemical characteristics of Buriganga
River water such as temperature, electric conductivity (EC), total dissolved oxygen (TDS), $\mathrm{pH}$, dissolved oxygen (DO), biological oxygen demand $\left(\mathrm{BOD}_{5}\right)$, chemical oxygen demand (COD), turbidity, chloride $\left(\mathrm{CL}^{-1}\right)$ and alkalinity between the periods of 2010-2020 is shown in Figure 2(a)2(k).

\subsection{Physical and Chemical Characteristics of Water in Buriganga River}

Mean temperature was recorded $(25.1 \pm 1.36)^{\circ} \mathrm{C}$ during winter season (February, 2020). Highest temperature was observed at Mirpur Bridge while the lowest in Dholaikhal (Fig. 2a). Mean values of TDS during winter season (February) ranged from $352.22 \pm 181.91$ to $720.88 \pm 233$ $\mathrm{mg} / \mathrm{l}$ whereas in summer (May) and rainy season (August) were $97.34 \pm 11.6$ to $690.06 \pm 116.28 \mathrm{mg} / \mathrm{l}$ and $58.12 \pm 2.0$ to $204 \pm 48.9 \mathrm{mg} / \mathrm{l}$ respectively. The highest TDS value was observed in winter season, 2011 while the lowest in rainy season, 2016 (Fig. 2b). Mean value of Electric conductivity (EC) during winter season (February) ranged from $704.44 \pm$ 284.08 to $1314.3 \pm 462.57 \mu \mathrm{S} / \mathrm{cm}$ whereas in summer (May) and rainy season (August) were $194.68 \pm 23.2$ to $1380.13 \pm 232.56 \mu \mathrm{S} / \mathrm{cm}$ and $116.24 \pm 4.02$ to $408 \pm 97.84$ $\mu \mathrm{S} / \mathrm{cm}$ respectively. The highest EC value was observed in summer season, 2014 while the lowest in rainy season, 2016 (Fig. 2c). Water $\mathrm{pH}$ ranged from $57.14 \pm 0.41$ to $7.43 \pm 0.17$ whereas in summer (May) and rainy season (August) were $6.98 \pm 0.21$ to $7.73 \pm 0.15$ and $6.75 \pm 0.38$ to $7.23 \pm 0.29$ respectively. The highest $\mathrm{pH}$ value was observed in summer season, 2010 while the lowest in rainy season, 2011 (Fig. $2 \mathrm{~d}$ ). Mean values of DO during winter season (February) ranged from $0 \pm 0$ to $0.89 \pm 0.43 \mathrm{mg} / \mathrm{l}$ whereas in summer (May) and rainy (August) season were $0.23 \pm 0.29$ to $2.93 \pm$ $0.63 \mathrm{mg} / \mathrm{l}$ and $2.03 \pm 0.45$ to $5.12 \pm 0.93 \mathrm{mg} / \mathrm{l}$ respectively (Fig. 2e). Mean values of BOD during winter season (February) ranged from $8.75 \pm 9.3$ to $25.38 \pm 6.28 \mathrm{mg} / \mathrm{l}$ whereas in summer (May) and rainy season (August) were $12.75 \pm 3.99$ to $32.13 \pm 8.2 \mathrm{mg} / \mathrm{l}$ and $0.5 \pm 0.93$ to $19.75 \pm$ $2.87 \mathrm{mg} / \mathrm{l}$ respectively. The highest BOD value was observed in summer season, 2011 while the lowest in rainy season, 2013 (Fig. 2f). Mean values of COD during winter season (February) ranged from $55.13 \pm 13.16$ to $105.63 \pm$ $38.31 \mathrm{mg} / 1$ whereas in summer (May) and rainy season (August) were $40.25 \pm 11.3$ to $115.63 \pm 41.4 \mathrm{mg} / \mathrm{l}$ and 10.71 \pm 1.2 to $63.25 \pm 13.05 \mathrm{mg} / \mathrm{l}$ respectively. The highest COD value was observed in summer season, 2012 while the lowest in rainy season, 2018 (Fig. 2g). Mean values of turbidity during winter season (February) ranged from 5.47 \pm 6.7 to $106.21 \pm 32.43 \mathrm{NTU}$ whereas in summer (May) and rainy (August) season were $6.81 \pm 1.3$ to $32.08 \pm 17.8 \mathrm{NTU}$ and $6.59 \pm 0.64$ to $77.46 \pm 10.38$ NTU respectively. The highest turbidity was observed in winter season, 2018 while the lowest in rainy season, 2016 (Fig. 2h). Mean values of chloride during winter season (February) ranged from 5.47 \pm 6.7 to $62.38 \pm 5.73 \mathrm{mg} / \mathrm{l}$ whereas in summer (May) and rainy (August) season were $19.25 \pm 2.92$ to $120.63 \pm 16.64$ $\mathrm{mg} / \mathrm{l}$ and $6 \pm 1.85$ to $15.44 \pm 3.87 \mathrm{mg} / \mathrm{l}$ respectively. The highest chloride value was observed in summer season, 2013(Fig. 2i). Mean values of SS during winter season (February) ranged from $22.63 \pm 5.9$ to $94.63 \pm 11.73 \mathrm{mg} / \mathrm{l}$ whereas in summer (May) and rainy (August) season were $8.63 \pm 5.37$ to $73.5 \pm 53.9 \mathrm{mg} / \mathrm{l}$ and $12.13 \pm 17.42$ to 85.71 
$\pm 13.89 \mathrm{mg} / \mathrm{l}$ respectively. The highest $\mathrm{SS}$ value was observed in winter season, 2018 while the lowest in rainy season, 2016 (Fig. 2j). Mean values of alkalinity during winter season (February) ranged from $106.11 \pm 56.14$ to $309 \pm 35.67 \mathrm{mg} / \mathrm{l}$ whereas in summer (May) and rainy (August) season were $27 \pm 4.0$ to $285 \pm 43.09 \mathrm{mg} / \mathrm{l}$ and $26.25 \pm 4.59$ to $202 \pm 22.37 \mathrm{mg} / \mathrm{l}$ respectively. The highest alkalinity value was observed in winter season, 2018 while the lowest in rainy season, 2014 (Fig. 2k).

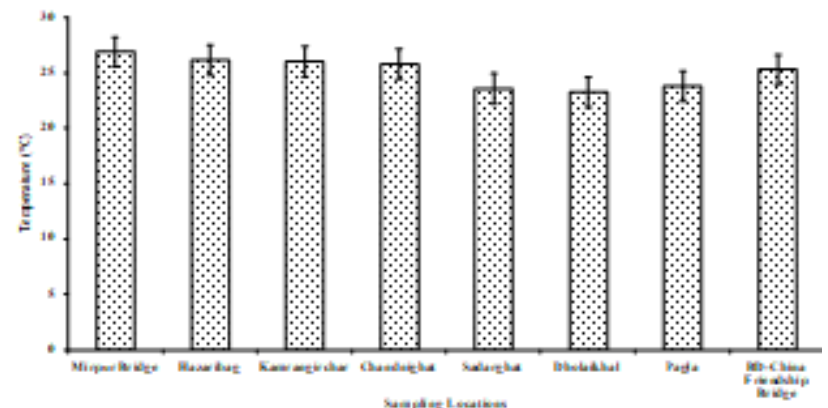

(a)

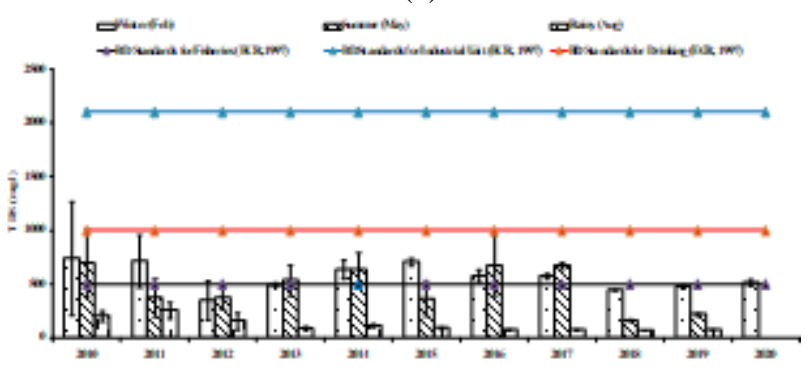

(b)

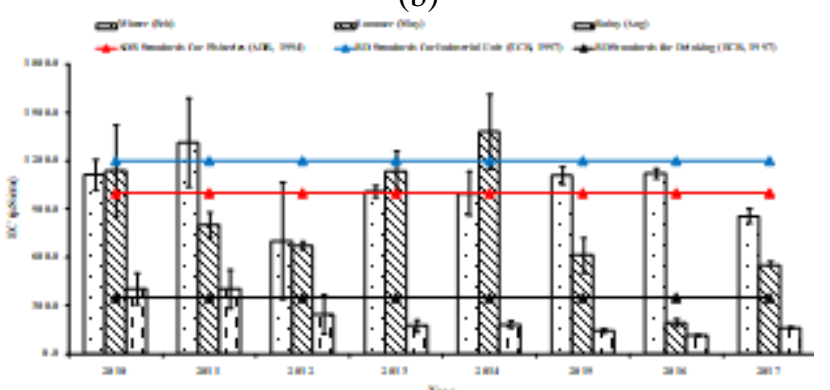

(c)

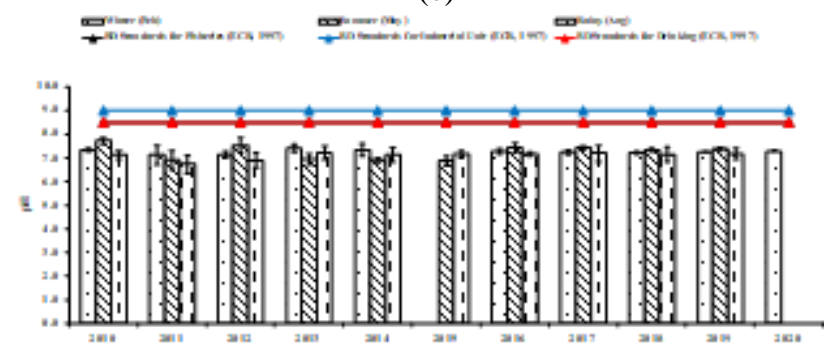

(d)

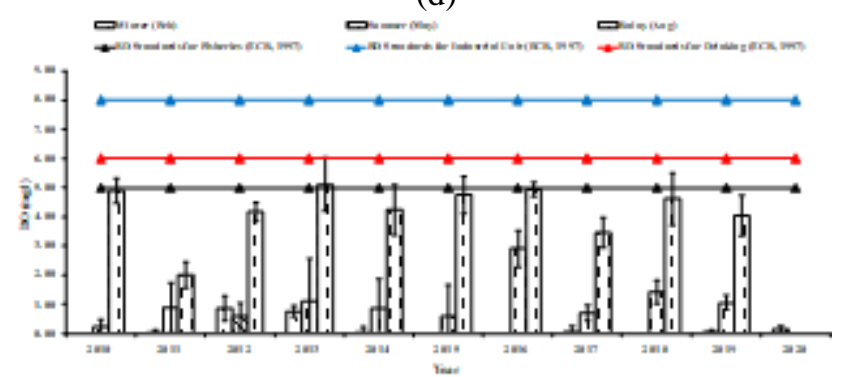

(e)

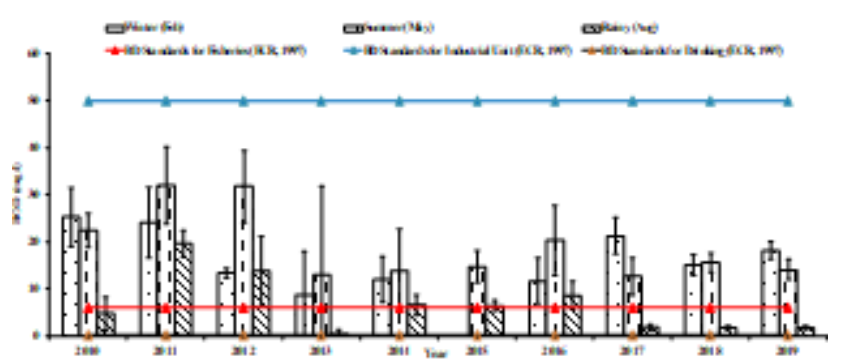

(f)

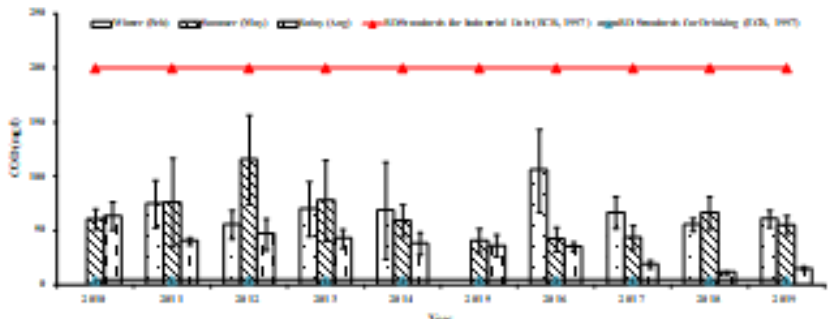

(g)

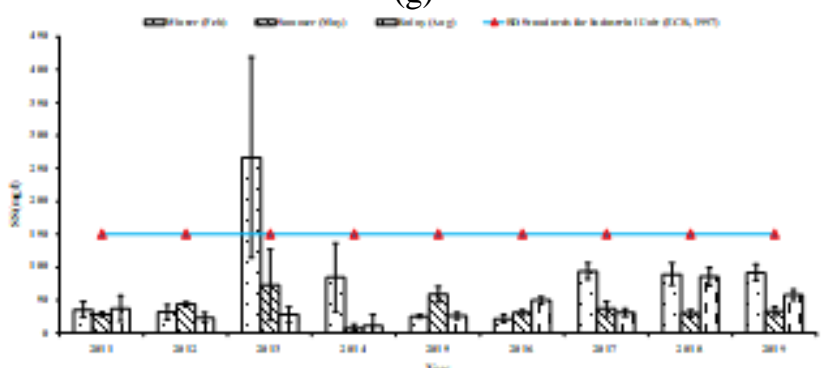

(h)

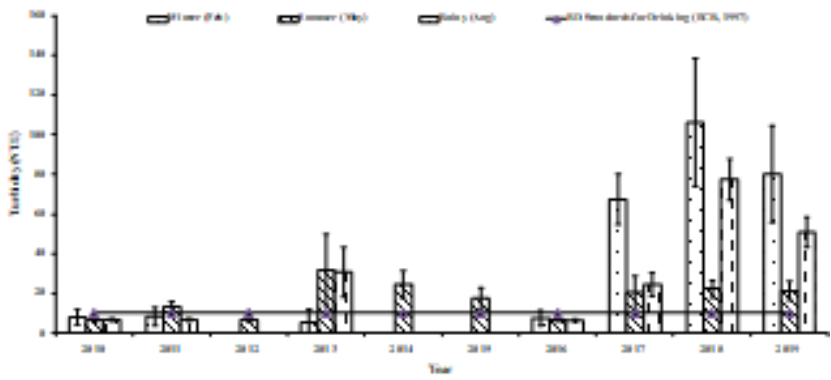

(i)



(j)



(k)

Figure 2: Physical and chemical characteristics of water in Buriganga River during winter, summer and rainy Season 
from 2010- 2020 (values are mean \pm SD) $(\mathrm{a}=$ Temperature $\mathrm{b}=$ Total Dissolved Solids, $\mathrm{c}=$ Electric Conductivity, $\mathrm{d}=$ $\mathrm{pH}, \mathrm{e}=$ Dissolved Oxygen, $\mathrm{f}=$ Biological Oxygen Demand, $\mathrm{g}=$ Chemical Oxygen Demand, $\mathrm{h}=$ Turbidity, $\mathrm{i}=$ Chloride, $\mathrm{j}$ = Suspended Solids, $\mathrm{k}=$ Alkalinity).

\subsection{Variation of Water Quality Index (WQI) from 2010- 2020}

Among the physical and chemical parameters TDS, EC, pH, DO, BOD, COD and Chloride were selected for calculating the Water Quality Index (WQI) of the Buriganga River. The highest WQI value was observed in summer (May) season 2011 while the lowest in rainy (August) season 2018. Variation of water quality index during winter, summer and rainy season from 2010 to 2020 is shown in Figure 3 - 6 .

\section{Winter Season}

The WQI value of the eight sampling locations in the Buriganga River during the winter season (2010-2020) is shown in Figure 3. The calculated values of WQI of the Buriganga River all the stations were greater than 100 (unsuitable for drinking) during the winter season (20102020). During the winter season (2010-2020), highest WQI value was observed in the year 2011 at Hazaribag while the lowest in 2020 at Sadarghat.

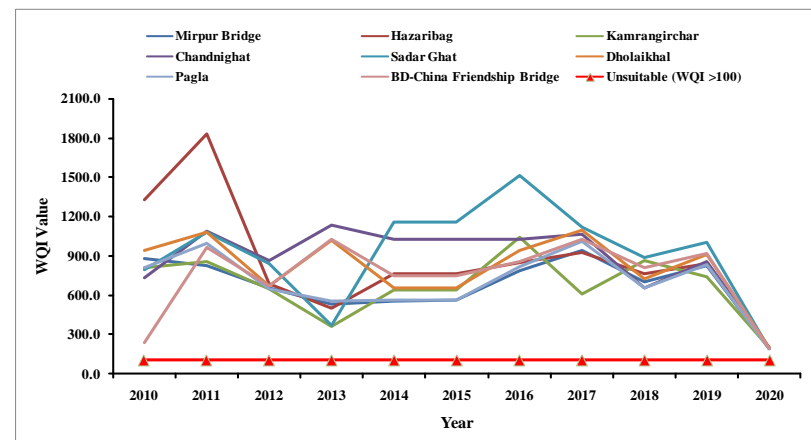

Figure 3: Water Quality Index of Buriganga River during winter season (2010-2020)

\section{Summer Season}

The WQI value of the eight sampling locations in the Buriganga River during the summer season (2010-2020) is shown in Figure 4. The calculated values of WQI of the Buriganga River all the stations were greater than 100 (unsuitable for drinking) during the summer season (20102019). During the summer season (2010-2019), highest WQI value was observed in the year 2011 at Hazaribag while the lowest in 2016 at Mirpur Bridge.

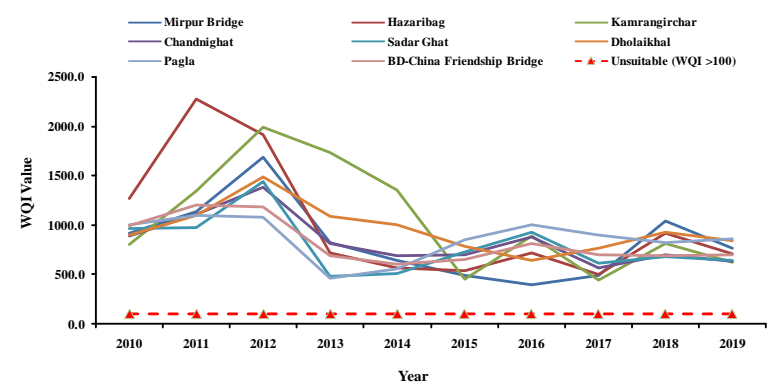

Figure 4: Water Quality Index of Buriganga River during summer season (2010-2019)

\section{Rainy Season}

The WQI value of the eight sampling locations in the Buriganga River during the rainy season (2010-2019) is shown in Figure 5. The calculated values of WQI of the Buriganga River all the stations were greater than 100 (unsuitable for drinking) during the rainy season (20102019). During the rainy season (2010-2019), highest WQI value was observed in the year 2012 at Pagla while the lowest in 2018 at BD-China Friendship Bridge.

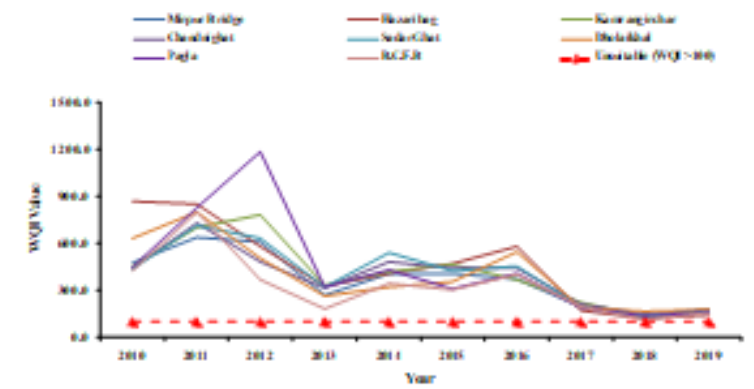

Figure 5: Water Quality Index of Buriganga River during rainy season (2010-2019)

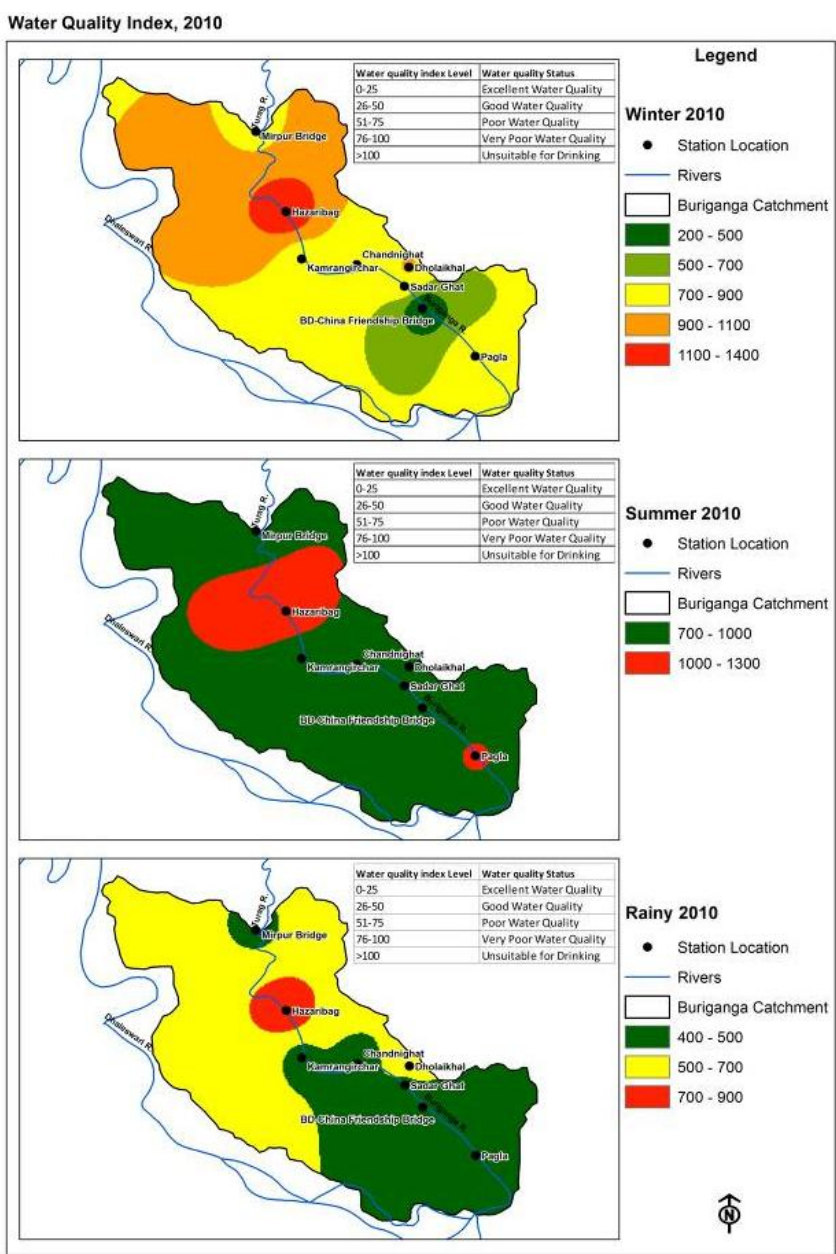

(a) 
Water Quality Index, 2011

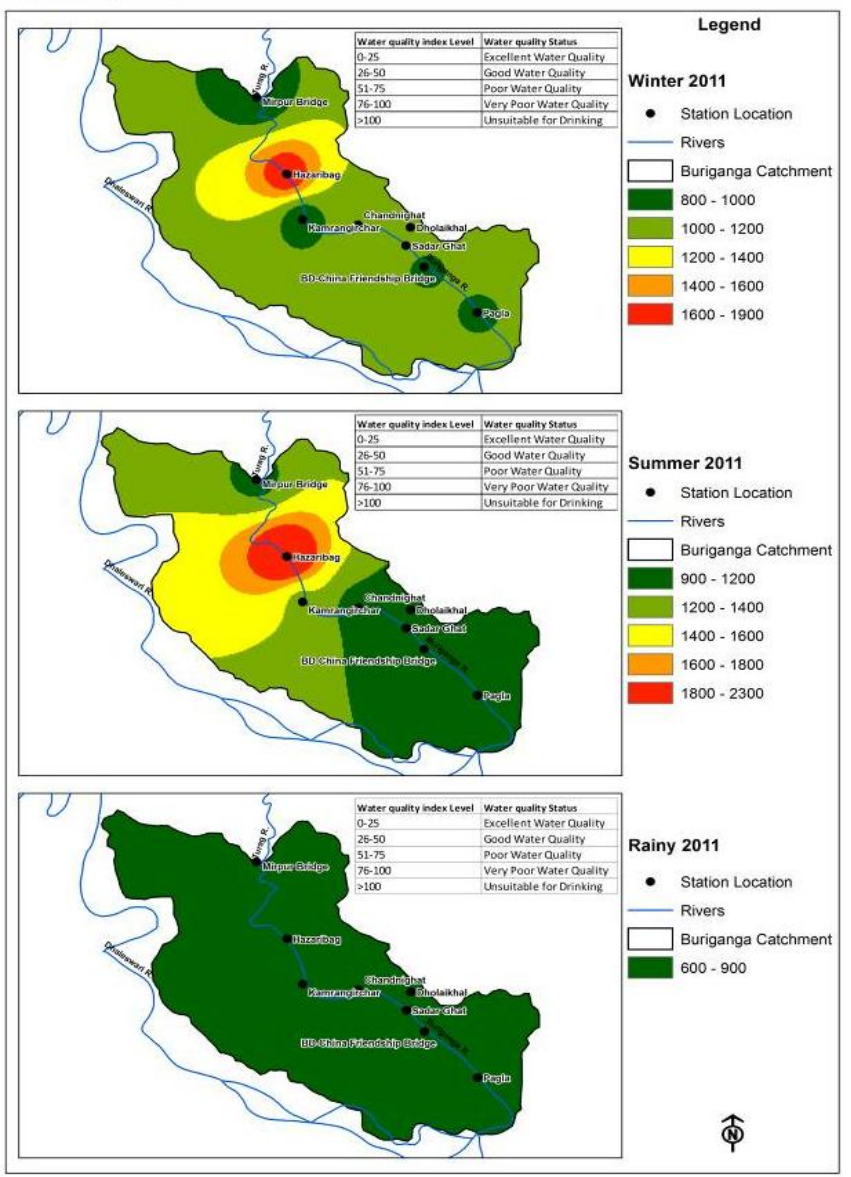

(b)

Water Quality Index, 2012

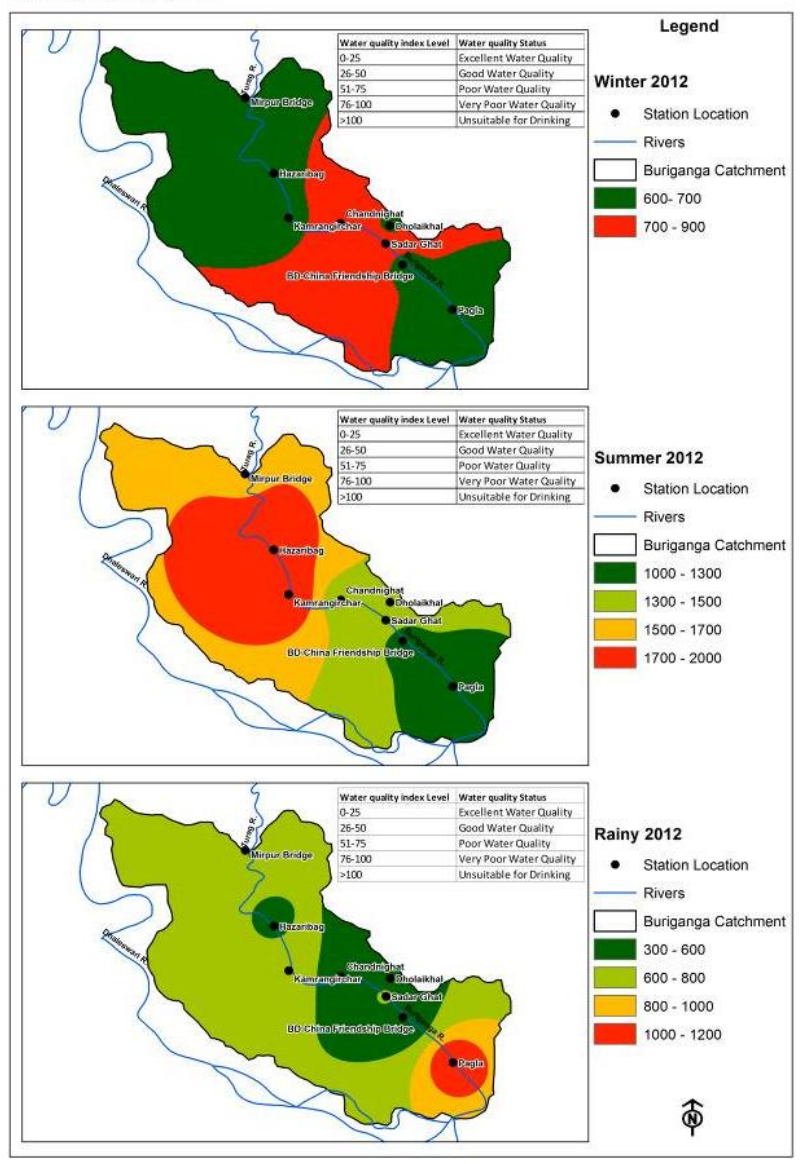

(c)
Water Quality Index, 2013

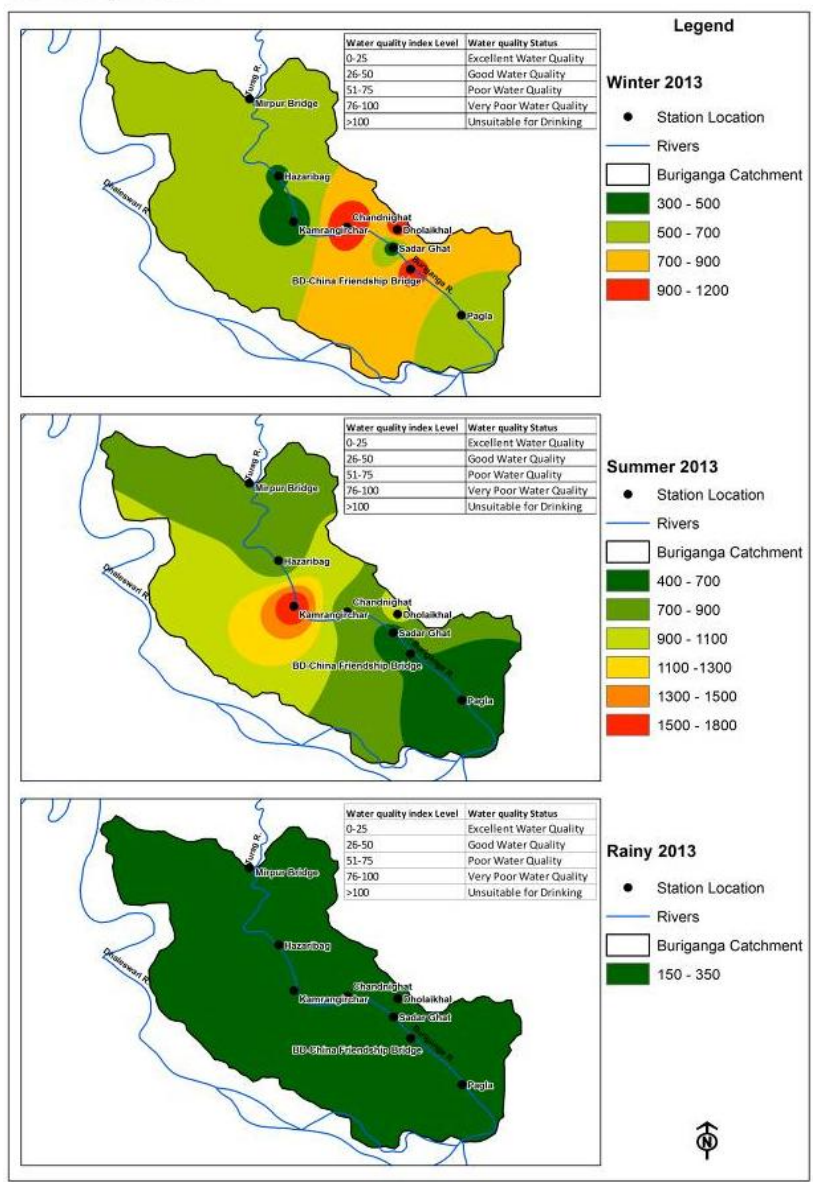

(d)

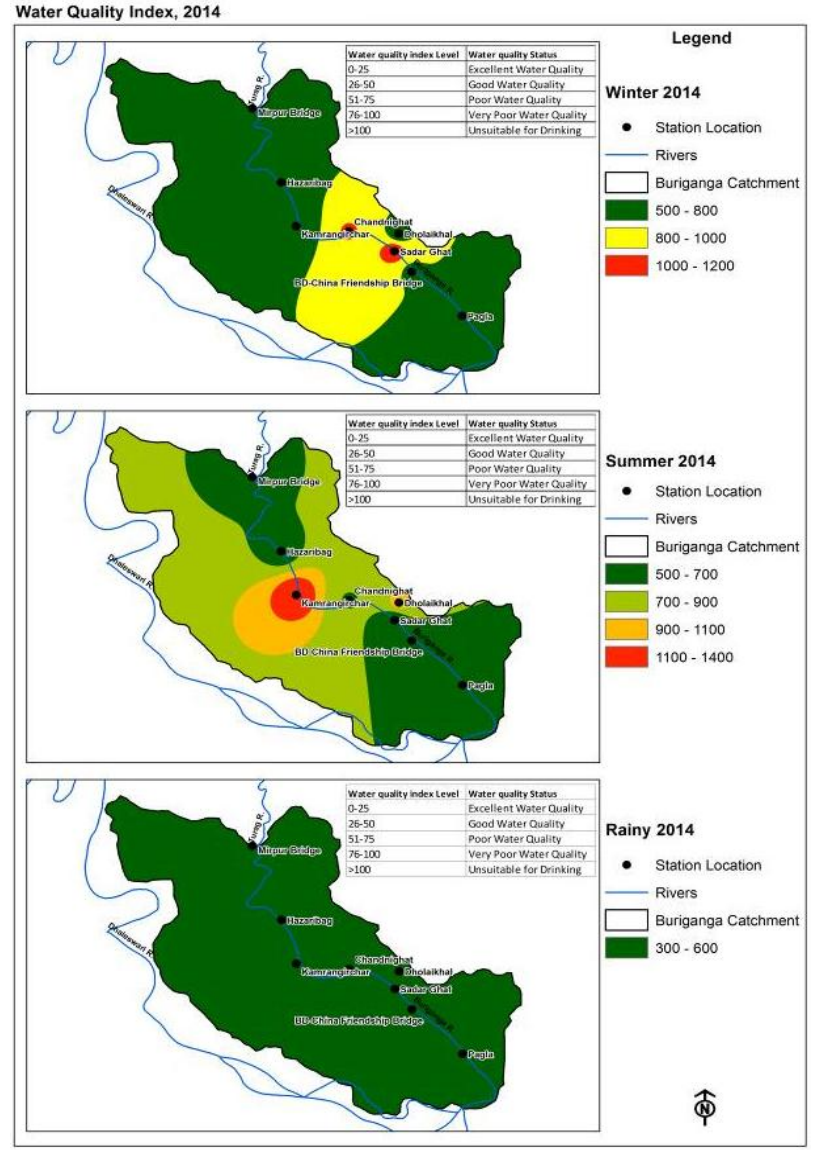

(e) 
Water Quality Index, 2019

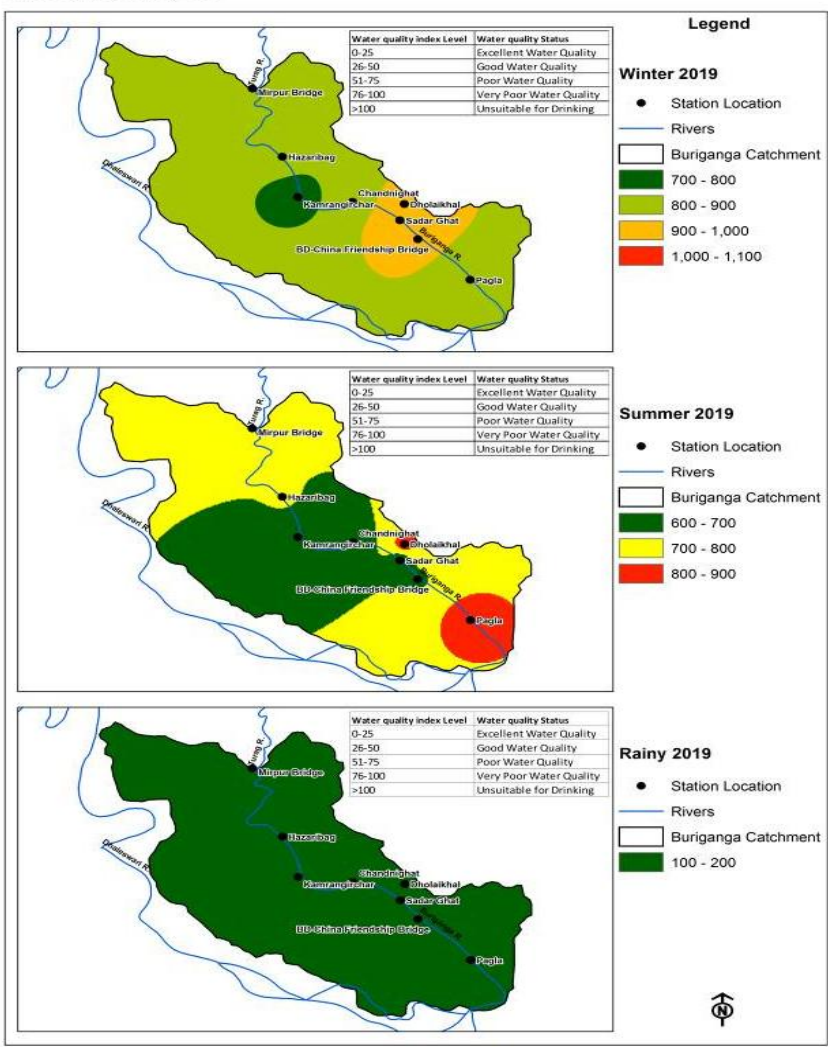

(j)

Water Quality Index, 2020

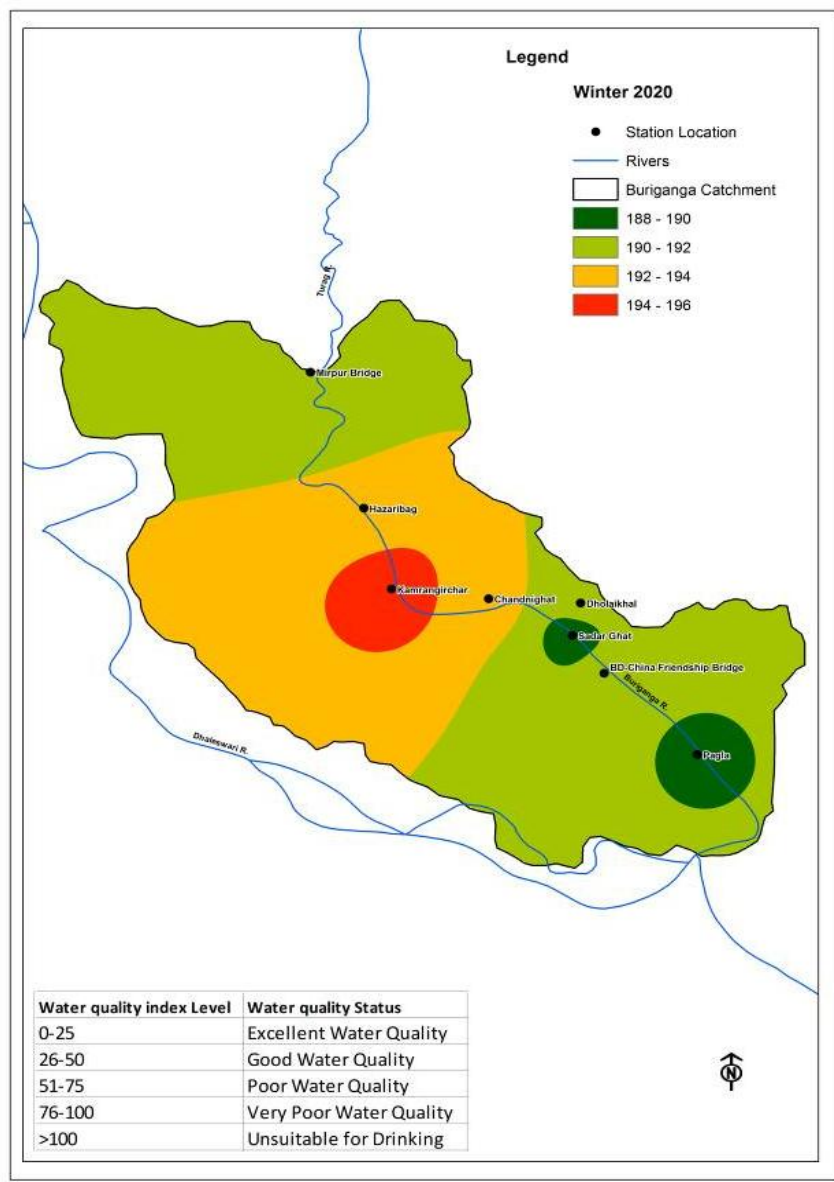

(k)

Figure 6: In Winter, Summer and Rainy seasons WQI for Buriganga River $(a=2010, b=2011, c=2012, d=2013$, e $=2014, \mathrm{f}=2015, \mathrm{~g}=2016, \mathrm{~h}=2017, \mathrm{i}=2018, \mathrm{j}=2019, \mathrm{k}$ $=2020)$

\section{Discussion}

In the present study, temperature of the Buriganga River water was recorded $23.3^{\circ} \mathrm{C}$ to $26.9^{\circ} \mathrm{C}$ during winter season (February, 2020). As per the Environmental Conservation Rules (ECR 1997), the accompanying requirements for temperature are endorsed: $20-30^{\circ} \mathrm{C}$ for fish culture, $20-30^{\circ} \mathrm{C}$ for drinking water and $40^{\circ} \mathrm{C}$ for industrial application. According to the observed values, the temperature is within the acceptable limit of DoE standard (Table 4).

Table 4: Standards for water [21]

\begin{tabular}{|c|c|c|c|c|}
\hline \multirow[b]{2}{*}{ Parameters } & \multirow[b]{2}{*}{ Unit } & \multicolumn{2}{|c|}{ Inland Surface Water } & \multirow[b]{2}{*}{$\begin{array}{c}\text { Drinking } \\
\text { water }\end{array}$} \\
\hline & & $\begin{array}{c}\text { Water usable } \\
\text { by fisheries }\end{array}$ & $\begin{array}{c}\text { Waste from } \\
\text { industrial units }\end{array}$ & \\
\hline Temperature & ${ }^{\circ} \mathrm{C}$ & $20-30$ & 40 & $20-30$ \\
\hline TDS & $\mathrm{mg} / \mathrm{l}$ & 500 & 2100 & 1000 \\
\hline $\mathrm{EC}$ & $\mu \mathrm{S} / \mathrm{cm}$ & ---- & 1200 & 350 \\
\hline $\mathrm{pH}$ & & $6.5-8.5$ & $6-9$ & $6.5-8.5$ \\
\hline DO & $\mathrm{mg} / \mathrm{l}$ & 5 or more & $4.5-8$ & 6 \\
\hline BOD & $\mathrm{mg} / \mathrm{l}$ & 6 of less & 50 & 0.2 \\
\hline COD & & ---- & 200 & 4 \\
\hline Turbidity & NTU & ---- & ---- & 10 \\
\hline Chloride & $\mathrm{mg} / \mathrm{l}$ & ---- & $150-600$ & $150-600$ \\
\hline TSS & $\mathrm{mg} / \mathrm{l}$ & ---- & 150 & ---- \\
\hline Alkalinity & $\mathrm{mg} / \mathrm{l}$ & ---- & 150 & ---- \\
\hline
\end{tabular}

During the study periods, TDS value ranged from 58.12 to $720.88 \mathrm{mg} / \mathrm{l}$. TDS range from 352.22 to $720.88 \mathrm{mg} / \mathrm{l}$ was recorded during winter (February) whereas in summer (May) and rainy season (August) were 97.34 to $690.06 \mathrm{mg} / \mathrm{l}$ and 58.12 to $204 \mathrm{mg} / \mathrm{l}$ respectively. As per the Environmental Conservation Rules [21] the accompanying requirements for TDS are endorsed: $500 \mathrm{mg} / \mathrm{l}$ for fish culture, $1000 \mathrm{mg} / \mathrm{l}$ for drinking water and $2100 \mathrm{mg} / \mathrm{l}$ for industrial application. TDS value was relatively low during rainy season compared to summer and winter season due to dilution effect. It is found that, TDS value was not suitable for fish production during winter and summer season.

Water of Buriganga River exhibited EC in the range of 116.24 to $1380.13 \mu \mathrm{S} / \mathrm{cm}$ during the study periods. EC range from 704.44 to $1314.25 \mu \mathrm{S} / \mathrm{cm}$ was recorded during winter (February) whereas in summer (May) and rainy season (August) were 194.68 to $1380.13 \mu \mathrm{S} / \mathrm{cm}$ and 116.24 to $408 \mu \mathrm{S} / \mathrm{cm}$ respectively. As per the Asian Development Bank [22] and Environmental Conservation Rules [21], the accompanying requirements for EC are endorsed: 1000 $\mu \mathrm{S} / \mathrm{cm}$ for aquaculture, $350 \mu \mathrm{S} / \mathrm{cm}$ for drinking water and $1200 \mu \mathrm{S} / \mathrm{cm}$ for industrial application. EC value was relatively low compared to summer and winter season due to dilution effect. It is found that, EC value was not suitable for drinking purposes. It is also seen that the EC value was not suitable for fish production during winter (February) season.

During the study periods, $\mathrm{pH}$ level ranged from 6.75 to 7.73. $\mathrm{pH}$ range from 7.14 to 7.43 was recorded during winter (February) whereas in summer (May) and rainy season (August) were 6.89 to 7.73 and 6.75 to 7.23 respectively. As per the Environmental Conservation Rules [21], the accompanying requirements for $\mathrm{pH}$ are endorsed: 6.5-8.5 for drinking \& fish culture and 6.0-9.0 for industrial application. It is found that, $\mathrm{pH}$ level was within the 
standard limit.

DO concentration ranged from 0 to $5.12 \mathrm{mg} / \mathrm{l}$ during the study periods. DO range from 0.0 to 0.89 was recorded during winter (February) whereas in summer (May) and rainy season (August) were 0.23 to $2.93 \mathrm{mg} / \mathrm{l}$ and 2.03 to $5.12 \mathrm{mg} / \mathrm{l}$ respectively. DO concentration of water was comparatively high during rainy season. This may be due to high organic and microbial activities with low volume of water during dry period. As per the Environmental Conservation Rules [21], the accompanying requirements for DO are endorsed: 5 or more $\mathrm{mg} / \mathrm{l}$ for fish culture, $6 \mathrm{mg} / \mathrm{l}$ for drinking and 4.5-8 mg/l for industrial application. It is found that, DO level was not suitable for fish production and environment.

BOD value ranged from 0.5 to $32.13 \mathrm{mg} / \mathrm{l}$ during the study periods. BOD range from 8.75 to $25.38 \mathrm{mg} / \mathrm{l}$ was recorded during winter (February) whereas in summer (May) and rainy season (August) were 12.75 to $32.13 \mathrm{mg} / \mathrm{l}$ and 0.5 to $19.75 \mathrm{mg} / \mathrm{l}$ respectively. BOD value was relatively low during rainy season compared to summer and winter season due to dilution effect. As per the Environmental Conservation Rules [21], the accompanying requirements for BOD are endorsed: 6 of less $\mathrm{mg} / \mathrm{l}$ for fish culture, 0.2 $\mathrm{mg} / \mathrm{l}$ drinking water for and $50 \mathrm{mg} / \mathrm{l}$ for industrial application. It is found that, BOD level was not suitable for fish production and drinking purposes.

During the study periods, COD value ranged from 10.71 to $115.63 \mathrm{mg} / \mathrm{l}$. COD range from 55.13 to $105.63 \mathrm{mg} / \mathrm{l}$ was recorded during winter (February) whereas in summer (May) and rainy season (August) were 40.25 to $115.63 \mathrm{mg} / \mathrm{l}$ and 10.71 to $63.25 \mathrm{mg} / \mathrm{l}$ respectively. COD value was relatively low during rainy season compared to summer and winter season due to dilution effect. As per the Environmental Conservation Rules [21], the accompanying requirements for $\mathrm{COD}$ are endorsed: $4 \mathrm{mg} / \mathrm{l}$ for drinking water and $200 \mathrm{mg} / \mathrm{l}$ for industrial application. It is found that, COD level was not suitable for drinking purposes.

In the present study, it was found that the turbidity values were in the range of 5.47 to 106.21 NTU. Turbidity range from 5.47 to $106.21 \mathrm{NTU}$ was recorded during winter (February) whereas in summer (May) and rainy season (August) were 6.81 to $32.08 \mathrm{NTU}$ and 6.59 to $77.46 \mathrm{NTU}$ respectively. As per the Environmental Conservation Rules [21], the accompanying requirements for turbidity are endorsed: $10 \mathrm{NTU}$ for drinking. High concentrations of Turbidity can cause many problems for stream health and aquatic life. It is found that, turbidity level was not suitable for drinking purposes.

Concentration of chloride during the study periods ranged from 5.47 to $120.63 \mathrm{mg} / \mathrm{l}$. Chloride content range from 5.47 to $62.38 \mathrm{mg} / \mathrm{l}$ was recorded during winter (February) whereas in summer (May) and rainy season (August) were 19.25 to $120.63 \mathrm{mg} / \mathrm{l}$ and 6 to $15.44 \mathrm{mg} / \mathrm{l}$ respectively. Chloride content of water was comparatively low during rainy season due to dilution effect. As per the World Bank, (1993) and Environmental Conservation Rules [21], the accompanying requirements for chloride are endorsed: 250 $\mathrm{mg} / \mathrm{l}$ for fish culture is and $150-600 \mathrm{mg} / \mathrm{l}$ for drinking and industrial application. It is found that, chloride value was within the permissible limit of DoE.

SS value ranged from 8.63 to $386.5 \mathrm{mg} / \mathrm{l}$ during the study periods. SS value range from 22.63 to $94.63 \mathrm{mg} / \mathrm{l}$ was recorded during winter (February) whereas in summer (May) and rainy season (August) were 8.63 to $73.5 \mathrm{mg} / \mathrm{l}$ and 12.13 to $85.71 \mathrm{mg} / \mathrm{l}$ respectively. TSS concentration of water was comparatively low during rainy (August) season due to dilution effect. According to Environmental Conservation Rules [21], the accompanying requirements for TSS are endorsed: $150 \mathrm{mg} / \mathrm{l}$ for industrial application. High concentrations of suspended solids can cause many problems for stream health and aquatic life. It is found that, TSS level was not suitable for fish production during winter season.

During the study periods, alkalinity value ranged from 26.25 to $309 \mathrm{mg} / \mathrm{l}$. Alkalinity value range from 106.11 to $309 \mathrm{mg} / \mathrm{l}$ was recorded during winter (February) whereas in summer (May) and rainy season (August) were 27 to 285 $\mathrm{mg} / \mathrm{l}$ and 26.25 to $202 \mathrm{mg} / \mathrm{l}$ respectively. Alkalinity concentration of water was comparatively low during rainy season due to dilution effect. As per the Bureau of Indian Standards (BIS, 1993) and Environmental Conservation Rules [21], the accompanying requirements for alkalinity are endorsed: $200 \mathrm{mg} / \mathrm{l}$ for drinking and $150 \mathrm{mg} / \mathrm{l}$ for industrial application. It is found that, alkalinity level was not suitable for fish production during winter and summer season. The sequence of water quality index (WQI) from 2010 to 2020 was $2011>2016>2017>2019>2015>$ $2014>2018>2012>2013>2020$ in the winter (February) season whereas in the summer (May) and rainy (August), season the order were $2012>2011>2010>2013>2018>$ $2016>2014>2019>2015>2017$ and $2011>2012>$ $2010>2016>2014>2015>2013>2017>2019>2018$ respectively. From the analysis it was observed that the water of this of this river is unsuitable for drinking purposes during winter, summer and rainy seasons.

\section{Conclusion}

Buriganga is one of the major rivers of Bangladesh. The Buriganga River is not only the lifeline of the capital city but also a perennial source of natural beauty for the common people of the country. Throughout this research, Dissolved Oxygen (DO), Biological Oxygen Demand (BOD), Chemical Oxygen Demand (COD) and Turbidity concentration crossed the maximum permissible range. Measured water quality index (WQI>100) displayed unsuitable for drinking purposes in winter, summer, and rainy season. However, water of Buriganga River was less polluted in rainy than in summer and winter season. The implication of these findings can be used to monitor health of riverine ecosystems which provide ecosystem services for society.

\section{References}

[1] Moniruzzaman, M., S. F. Elahi and M. A. A. Jahangir, 2010. Study on Temporal Variation of Physicochemical Parameters of Buriganga River Water through 
GIS Geographical Information System) Technology Bangladesh, Journal of Scientific and Industrial Research, 44: 8

[2] BSS. "4 rivers around city declared ecologically critical area". The Daily Star, 24 November 2009

[3] Uddin, M. G., M. Moniruzzaman., M. A. A. Hoque., M. A. Hasan and M. Khan, 2016. Seasonal Variation of Physicochemical Properties of Water in the Buriganga River, Bangladesh, Journal of World Applied Sciences, 34(1):24- 34

[4] Ali, M. Y., M. N. Amin and K. Alam, 2008. Ecological Health Risk of Buriganga River, Dhaka, Bangladesh, Hydro Nepal, Journal of Water, Energy and Environment, 3: 25-28

[5] Islam, M.S., R. Afroz and M. B. Mia, 2019. Investigation of Surface Water Quality of the Buriganga River in Bangladesh: Laboratory and Spatial Analysis Approaches, Dhaka Univ. J. Biol. Sci. 28(2):147-158

[6] Fatema, K., M. Begum, M. Al Zahid and M. E.Hossain, 2018. Water Quality Assessment of the River Buriganga, Bangladesh, Journal of Biodiversity Conservation and Bioresource Management, 4(1): 4754

[7] Akbor, M. A., M. k. Uddin and M. A. Ahsan, 2017. Investigation of Water Quality Parameters at Different Points in the Buriganga River, Bangladesh, J. Environ. Sci. \& Natural Resources, 10(1): 75-80

[8] Mottalib, M. A., S. Roy., M. S. Ahmed., M. Khan and A. N. M. Al-Razee, 2017. Comparative Study of Water Quality of Buriganga and Balu River, Dhaka, Bangladesh, International Journal of Current Research, 9(10):59132-59137.

[9] Ahammed, S. S., S. Tasfina., K. A. Rabbani and M. A. Khaleque, 2016. An Investigation into the Water Quality of Buriganga- A River Running Through Dhaka

[10] Rahman, M. A. and D. Al Bakri, 2010. A Study on Selected Water Quality Parameters along the River Buriganga, Bangladesh Iranica Journal of Energy and Environment, 1: 81-92

[11]DOE, 2011. River water quality Report, Ministry of Environment and Forest, Government of Bangladesh.

[12] DOE, 2012. River water quality Report, Ministry of Environment and Forest, Government of Bangladesh.

[13]DOE, 2013. River water quality Report, Ministry of Environment and Forest, Government of Bangladesh.

[14] DOE, 2014. River water quality Report, Ministry of Environment and Forest, Government of Bangladesh.

[15]DOE, 2015. River water quality Report, Ministry of Environment and Forest, Government of Bangladesh.

[16] DOE, 2016. River water quality Report, Ministry of Environment and Forest, Government of Bangladesh.

[17]DOE, 2017. Surface and Groundwater water quality Report, Ministry of Environment and Forest, Government of Bangladesh

[18]DOE, 2018. Surface and Groundwater water quality Report, Ministry of Environment, Forests and Climate Change, Government of Bangladesh.

[19] Brown, R. M., McCleiland, N. I., Deininger, R. A., \& Tozer, R. G, 1970. A Water Quality Index: Do we dare? Water and Sewage Works, 117, 339-343
[20] Chaterjee, C. and M. Raziuddin, 2002. Determination of Water Quality Index of a Degraded River in Asansol Industrial Area, Raniganj, Burdwan, West Bengal, Nature, Environment and Pollution Technology, 1(2):181-189.

[21]ECR, 1997. Government of the People's Republic of Bangladesh. Ministry of Environment and Forest, Department of Environment, Dhaka, Bangladesh, pp. 205-214.

[22]ADB, 1994. Training Manual for Environmental Monitoring. Environmental Science Incorporation, USA, pp. 2-26. 